\title{
Synthesis and Styrene Copolymerization of New Halogen and Methoxy Ring-Trisubstituted Propyl Cyanophenylpropenoates
}

\author{
Yesenia L. Soto ${ }^{1}$, Emily A. Baumgartner ${ }^{1}$, Francesca R. Bertoletti ${ }^{1}$, Ellen F. Gardner ${ }^{1}$, Bridget M. Hofsteadter ${ }^{1}$, Adis \\ Hrvat $^{1}$, Aurimas Jackunas ${ }^{1}$, Alex J. Jagla ${ }^{1}$, Justus V. Winter ${ }^{1}$, Danielle S. Ostrovsky ${ }^{1}$, William S. Schjerven ${ }^{1}$, Gregory B. \\ Kharas $^{1}$ \\ ${ }^{1}$ Chemistry Department, DePaul University, Chicago, USA \\ Correspondence: Gregory B. Kharas, Chemistry Department, DePaul University, 1110 West Belden Avenue, Chicago, IL \\ 60614-3214, USA. Tel: 1-773-325-7367.E-mail: gkharas@depaul.edu
}

Received: June 4, 2019 Accepted: June 23, 2019 Online Published: June 27, 2019

doi:10.5539/ijc.v11n2p60 URL: https://doi.org/10.5539/ijc.v11n2p60

\begin{abstract}
New ring-trisubstituted propyl cyanophenylpropenoates, $\quad \mathrm{RPhCH}=\mathrm{C}(\mathrm{CN}) \mathrm{CO}_{2} \mathrm{C}_{3} \mathrm{H}_{7} \quad$ (where $\mathrm{R} \quad$ is 2-bromo-3-hydroxy-4-methoxy, 5-bromo-2,3-dimethoxy, 5-bromo-2,4-dimethoxy, 6-bromo-3,4-dimethoxy, 2-chloro-3,4-dimetoxy, 5-chloro-2,3-dimetoxy, 4-bromo-2,6-difluoro, 3-chloro-2,6-difluoro, 4-chloro-2,6-difluoro) were prepared by the piperidine catalyzed Knoevenagel condensation of ring-trisubstituted benzaldehydes and propyl cyanoacetate and characterized by $\mathrm{CHN}$ elemental analysis, IR, ${ }^{1} \mathrm{H}$ and ${ }^{13} \mathrm{C}-\mathrm{NMR}$. The propenoates formed copolymers with styrene in solution with radical initiation $(\mathrm{ABCN})$ at $70^{\circ} \mathrm{C}$. The copolymers were characterized by nitrogen elemental analysis, IR, ${ }^{1} \mathrm{H}$ and ${ }^{13} \mathrm{C}-\mathrm{NMR}$, DSC. Decomposition of the copolymers in nitrogen (TGA) occurred in two steps, first in the $200-500^{\circ} \mathrm{C}$ range with residue (4.2-8.1\% wt.), which then decomposed in the $500-800^{\circ} \mathrm{C}$ range.
\end{abstract}

Keywords: trisubstituted ethylenes, cyanophenylpropenoates, styrene copolymers, functional monomers, functional polymers

\section{Introduction}

Ring-substituted cyanophenylpropenoates, $\mathrm{R}^{1} \mathrm{PhCH}=\mathrm{C}(\mathrm{CN}) \mathrm{CO}_{2} \mathrm{R}^{2}$ have been used in a variety of applications as well as comonomers in copolymerization with electrophilic vinyl monomers. Thus cyanophenylpropenoates were used in synthesis and evaluation of antifungal and antibacterial activity of ethyl 3,5-diarylisoxazole-4-carboxylates (Kumar et al., 2001) as well as in synthesis and structure-activity relationship study of substituted caffeate esters as antinociceptive agents (Rodrigues et al., 2014). The esters were components in synthesis of novel azo disperse dyes incorporating pyrazolo[1,5-a]pyrimidines for dyeing of polyester fabrics (Sayed et al., 2012). A new photoreactive polyester was prepared by addition reaction of bisepoxide with $\beta$-truxinoyl chloride followed by chemical modification (Nishikubo et al., 1995). Cyanophenylpropenoates were copolymerized with acrylic esters (Angelovici \& Kohn 1990) and terpolymerized with acrylonitrile and styrene (Ronel \& Kohn 1975). Chiral propyl cyanocinnamate was utilized in conjugate addition asymmetric enolate trapping reactions (Cativiela et al., 1992). Improved photosensitivity was achieved via intermolecular photocrosslinking of poly(vinyl cinnamate) derivatives (Watanabe \& Ichimura 1982).

Most cyanophenylpropenoates do not homopolymerize due to steric difficulties but copolymerize readily with electron-rich monomers such as styrene, $N$-vinylcarbazole, and vinyl acetate (Hall \& Daly 1975, Hall \& Ikman 1977, Kharas 1996).

Earlier we have reported synthesis and styrene copolymerization of halogen and methoxy ring-trisubstituted methyl (Kharas et al., 2014) and butyl (Kharas et al., 2016) cyanophenylpropenoates. Our purposes in exploration of novel propyl cyanophenylpropenoates were twofold: (1) to utilize aldol condensation for synthesis of alkenes with a variety of potentially reactive functional groups; (2) to employ conventional radical copolymerization of novel functional comonomers with a commercial monomer styrene. Thus, in continuation of our investigation of new of propyl cyanophenylpropenoates (Bates et al., 2019, Humanski et al., 2018, Kharas et al., 2017) we have prepared halogen and methoxy ring-trisubstituted propyl cyanophenylpropenoates (PCPP), $\quad \mathrm{RPhCH}=\mathrm{C}(\mathrm{CN}) \mathrm{CO}_{2} \mathrm{C}_{3} \mathrm{H}_{7}, \quad$ where $\mathrm{R}$ is 2-bromo-3-hydroxy-4-methoxy, 5-bromo-2,3-dimethoxy, 5-bromo-2,4-dimethoxy, 6-bromo-3,4-dimethoxy, 2-chloro-3,4-dimetoxy, 5-chloro-2,3-dimetoxy, 4-bromo-2,6-difluoro, 3-chloro-2,6-difluoro, 4-chloro-2,6-difluoro, and explore the feasibility of their copolymerization with styrene. To the best of our knowledge, there have been no reports on either synthesis of these propyl cyanophenylpropenoates, nor their copolymerization with styrene. 


\section{Experimental}

\subsection{Materials}

2-Bromo-3-hydroxy-4-methoxy (98\%), 5-bromo-2,3-dimethoxy $\quad(\geq 97.5 \%), \quad$ 5-bromo-2,4-dimethoxy $\quad$ (98\%), 6-bromo-3,4-dimethoxy (96\%), 2-chloro-3,4-dimetoxy ( $\geq 96 \%)$, 5-chloro-2,3-dimetoxy (97\%), 4-bromo-2,6-difluoro (98\%), 3-chloro-2,6-difluoro ( $\geq 95 \%)$, 4-chloro-2,6-difluoro ( $(\geq 97.5 \%)$ substituted benzaldehydes, propyl cyanoacetate $(\geq 98.0 \%)$, piperidine (99\%), styrene (99\%), 1,1'-azobiscyclohexanecarbonitrile, (ABCN) (98\%), and toluene (99.8\%) supplied from Sigma-Aldrich Co., were used as received.

\subsubsection{General Procedures}

IR spectra of the PCPP compounds and polymers ( $\mathrm{NaCl}$ plates) were determined with an ABB FTLA 2000 FT-IR spectrometer. The melting points of the PCPP compounds and the glass transition temperatures $\left(T_{\mathrm{g}}\right)$, of the copolymers were measured with TA (Thermal Analysis, Inc.) Model Q10 differential scanning calorimeter (DSC). The thermal scans were performed in a 25 to $200^{\circ} \mathrm{C}$ range on second heat at heating rate of $10^{\circ} \mathrm{C} / \mathrm{min}$. $T_{\mathrm{g}}$ was taken as a midpoint of a straight line between the inflection of the peak's onset and endpoint. The thermal stability of the copolymers was measured by thermogravimetric analyzer (TGA) TA Model Q50 from ambient temperature to $800^{\circ} \mathrm{C}$ at $20^{\circ} \mathrm{C} / \mathrm{min}$ in the flow of nitrogen $(20 \mathrm{~mL} / \mathrm{min})$. The molecular weights of the polymers was determined relative to polystyrene standards in THF solutions with sample concentrations $0.8 \%$ (w/v) by gel permeation chromatography (GPC) using a Altech 426 HPLC pump at an elution rate of $1.0 \mathrm{~mL} / \mathrm{min}$; Phenogel $5 \mu$ Linear column at $25^{\circ} \mathrm{C}$ and Viscotek 302 RI detector. ${ }^{1} \mathrm{H}$ - and ${ }^{13} \mathrm{C}-\mathrm{NMR}$ spectra were obtained on 10-25\% (w/v) PCC or polymer solutions in $\mathrm{CDCl}_{3}$ at ambient temperature using Bruker Avance $300 \mathrm{MHz}$ spectrometer. Elemental analyses of were performed by Midwest Microlab, LLC (IN).

\section{Results and Discussion}

\subsection{Synthesis and Characterization of Propyl Cyanophenylpropenoates}

The ring-trisubstituted propyl cyanophenylpropenoates (PCPP) were prepared via Knoevenagel condensation (Smith \& March 2001) of appropriate benzaldehydes with propyl cyanoacetate, catalyzed by piperidine (Scheme 1).

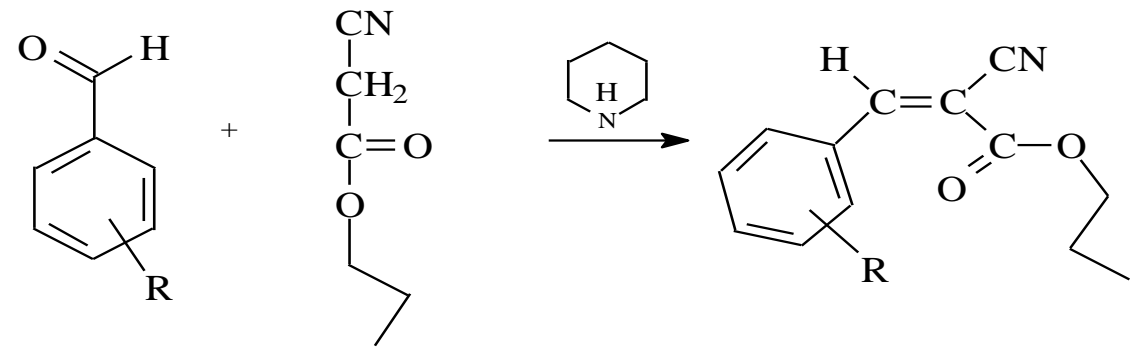

Scheme 1. Synthesis of propyl cyanophenylpropenoates

where $\mathrm{R}$ is 2-bromo-3-hydroxy-4-methoxy, 5-bromo-2,3-dimethoxy, 5-bromo-2,4-dimethoxy, 6-bromo-3,4-dimethoxy, 2-chloro-3,4-dimetoxy, 5-chloro-2,3-dimetoxy, 4-bromo-2,6-difluoro, 3-chloro-2,6-difluoro, 4-chloro-2,6-difluoro.

The cyanophenylpropenoates were prepared by mixing equimolar amounts of propyl cyanoacetate and an appropriate benzaldehyde, together with $0.2 \mathrm{~g}$ of piperidine. The product was recrystallized in propyl alcohol. No stereochemical analysis of the novel ring-trisubstituted PCPP was performed since no stereoisomers ( $E$ or/and $Z$ ) of known configuration were available.

Propyl 2-cyano-3-(2-bromo-3-hydroxy-4-methoxyphenyl)-2-propenoate

Yield 73\%; mp $158^{\circ} \mathrm{C},{ }^{1} \mathrm{H}-\mathrm{NMR} \delta 8.6(\mathrm{~s}, 1 \mathrm{H}, \mathrm{CH}=), 7.1-6.8(\mathrm{~m}, 2 \mathrm{H}, \mathrm{Ph}), 4.4\left(\mathrm{t}, 2 \mathrm{H}, \mathrm{OCH}_{2}, \mathrm{~J}=7.3 \mathrm{~Hz}\right), 3.8\left(\mathrm{~s}, 3 \mathrm{H}, \mathrm{OCH}_{3}\right)$, $1.7\left(\mathrm{sx}, 2 \mathrm{H}, \mathrm{CH}_{2}, \mathrm{~J}=7.3 \mathrm{~Hz}\right), 1.0\left(\mathrm{t}, 3 \mathrm{H}, \mathrm{CH}_{3}, \mathrm{~J}=7.3 \mathrm{~Hz}\right) ;{ }^{13} \mathrm{C}-\mathrm{NMR} \delta 163(\mathrm{C}=\mathrm{O}), 152(\mathrm{HC}=), 158,129,128,113(\mathrm{Ph})$, $116(\mathrm{CN}), 102(\mathrm{C}=), 67\left(\mathrm{OCH}_{2}\right), 56\left(\mathrm{OCH}_{3}\right), 22\left(\mathrm{OCH}_{2} \mathrm{CH}_{2}\right), 10\left(\mathrm{OCH}_{2} \mathrm{CH}_{2} \underline{\mathrm{CH}}_{3}\right) ; \mathrm{IR}\left(\mathrm{cm}^{-1}\right): 3127-2822(\mathrm{~m}, \mathrm{C}-\mathrm{H}), 2225$ (m, CN), 1705 (s, C=O), 1568 (s, C=C), 1265 (s, C-O-C), 828 (s, C-H out of plane). Anal. Calcd. for $\mathrm{C}_{14} \mathrm{H}_{14} \mathrm{BrNO}_{4}: \mathrm{C}$, 49.43; H, 4.15; N, 4.12; Found: C, 49.48; H, 4.13; N, 4.06.

Propyl 2-cyano-3-(5-bromo-2,3-dimethoxyphenyl)-2-propenoate

Yield 92\%; mp 78 ${ }^{\circ} \mathrm{C},{ }^{1} \mathrm{H}-\mathrm{NMR} \delta 8.6(\mathrm{~s}, 1 \mathrm{H}, \mathrm{CH}=), 8.1-7.1(\mathrm{~m}, 2 \mathrm{H}, \mathrm{Ph}), 4.3\left(\mathrm{t}, 2 \mathrm{H}, \mathrm{OCH}_{2}, \mathrm{~J}=7.3 \mathrm{~Hz}\right), 3.9\left(\mathrm{~s}, 6 \mathrm{H}, \mathrm{CH}_{3}\right)$, $1.8\left(\mathrm{sx}, 2 \mathrm{H}, \mathrm{CH}_{2}, \mathrm{~J}=7.3 \mathrm{~Hz}\right), 0.9\left(\mathrm{t}, 3 \mathrm{H}, \mathrm{CH}_{3}, \mathrm{~J}=7.3 \mathrm{~Hz}\right) ;{ }^{13} \mathrm{C}-\mathrm{NMR} \delta 163(\mathrm{C}=\mathrm{O}), 152(\mathrm{HC}=), 153,152,132,112(\mathrm{Ph})$, $116(\mathrm{CN}), 111(\mathrm{C}=), 68\left(\mathrm{O}_{\underline{C}}\right), 60,56\left(\mathrm{OCH}_{3}\right), 22\left(\mathrm{OCH}_{2} \underline{\mathrm{CH}}_{2}\right), 10\left(\mathrm{OCH}_{2} \mathrm{CH}_{2} \underline{\mathrm{CH}_{3}}\right) ; \mathrm{IR}\left(\mathrm{cm}^{-1}\right): 2969-2833(\mathrm{~m}, \mathrm{C}-\mathrm{H})$, $2224(\mathrm{~m}, \mathrm{CN}), 1727$ (s, C=O), 1605 (s, C=C), 1263 (s, C-O-C), 822 (s, C-H out of plane). Anal. Calcd. for $\mathrm{C}_{15} \mathrm{H}_{16} \mathrm{BrNO}_{4}$ : C, 50.87; H, 4.55; N, 3.95; Found: C, 50.58; H, 4.63; N, 3.95 . 
Propyl 2-cyano-3-(5-bromo-2,4-dimethoxyphenyl)-2-propenoate

Yield 84\%; mp $156^{\circ} \mathrm{C},{ }^{1} \mathrm{H}-\mathrm{NMR} \delta 8.6(\mathrm{~s}, 1 \mathrm{H}, \mathrm{CH}=), 8.3-6.7(\mathrm{~m}, 2 \mathrm{H}, \mathrm{Ph}), 4.3\left(\mathrm{t}, 2 \mathrm{H}, \mathrm{OCH}_{2}, \mathrm{~J}=7.3 \mathrm{~Hz}\right), 3.9(\mathrm{~s}, 6 \mathrm{H}$, $\left.\mathrm{OCH}_{3}\right), 1.7\left(\mathrm{~m}, 2 \mathrm{H}, \mathrm{CH}_{2}, \mathrm{~J}=7.3 \mathrm{~Hz}\right), 1.0\left(\mathrm{t}, 3 \mathrm{H}, \mathrm{CH}_{3}, \mathrm{~J}=7.3 \mathrm{~Hz}\right) ;{ }^{13} \mathrm{C}-\mathrm{NMR} \delta 163(\mathrm{C}=\mathrm{O}), 152(\mathrm{HC}=), 131,126,123,114$ $(\mathrm{Ph}), 116(\mathrm{CN}), 100(\mathrm{C}=), 67\left(\mathrm{OCH}_{2}\right), 56\left(\mathrm{OCH}_{3}\right), 22\left(\mathrm{OCH}_{2} \underline{C H}_{2}\right), 10\left(\mathrm{OCH}_{2} \mathrm{CH}_{2} \underline{C H}_{3}\right) ; \mathrm{IR}\left(\mathrm{cm}^{-1}\right): 3230-2840(\mathrm{~m}, \mathrm{C}-\mathrm{H})$, 2219 (m, CN), 1728 (s, C=O), 1537 (s, C=C), 1269 (s, C-O-C), 878 (s, C-H out of plane). Anal. Calcd. for $\mathrm{C}_{15} \mathrm{H}_{16} \mathrm{BrNO}_{4}$ : C, 50.87; H, 4.55; N, 3.95; Found: C, 50.52; H, 4.76; N, 3.46.

Propyl 2-cyano-3-(6-bromo-3,4-dimethoxyphenyl)-2-propenoate

Yield 71\%; mp $152^{\circ} \mathrm{C},{ }^{1} \mathrm{H}-\mathrm{NMR} \delta 8.1(\mathrm{~s}, 1 \mathrm{H}, \mathrm{CH}=), 7.7-6.8(\mathrm{~m}, 2 \mathrm{H}, \mathrm{Ph}), 4.2\left(\mathrm{t}, 2 \mathrm{H}, \mathrm{OCH}_{2}, \mathrm{~J}=7.3 \mathrm{~Hz}\right), 4.1(\mathrm{~s}, 6 \mathrm{H}$, $\left.\mathrm{OCH}_{3}\right), 1.7\left(\mathrm{sx}, 2 \mathrm{H}, \mathrm{OCH}_{2}\right), 1.0\left(\mathrm{t}, 3 \mathrm{H}, \mathrm{OCH}_{3}, \mathrm{~J}=7.3 \mathrm{~Hz}\right) ;{ }^{13} \mathrm{C}-\mathrm{NMR} \delta 163(\mathrm{C}=\mathrm{O}), 152(\mathrm{HC}=), 131,124,113,100(\mathrm{Ph})$, $116(\mathrm{CN}), 96(\mathrm{C}=), 67\left(\mathrm{OCH}_{2}\right), 56\left(\mathrm{OCH}_{3}\right), 22\left(\mathrm{OCH}_{2} \mathrm{CH}_{2}\right), 10\left(\mathrm{OCH}_{2} \mathrm{CH}_{2} \mathrm{CH}_{3}\right) ; \mathrm{IR}\left(\mathrm{cm}^{-1}\right): 3054-2810(\mathrm{~m}, \mathrm{C}-\mathrm{H}), 2211$ (m, CN), 1724 (s, C=O), 1580 (s, C=C), 1221 (s, C-O-C), 825 (s, C-H out of plane). Anal. Calcd. for $\mathrm{C}_{15} \mathrm{H}_{16} \mathrm{NO}_{4}$ : $\mathrm{C}$, 50.87 ; H, 4.55; N, 3.95; Found: C, 50.39; H, 4.47; N, 3.74.

Propyl 2-cyano-3-(2-chloro-3,4-dimetoxyphenyl)-2-propenoate

Yield 92\%; mp $110^{\circ} \mathrm{C},{ }^{1} \mathrm{H}-\mathrm{NMR} \delta 8.6(\mathrm{~s}, 1 \mathrm{H}, \mathrm{CH}=), 8.2-7.7(\mathrm{~m}, 2 \mathrm{H}, \mathrm{Ph}), 4.3\left(\mathrm{t}, 2 \mathrm{H}, \mathrm{OCH}_{2}, \mathrm{~J}=7.3 \mathrm{~Hz}\right), 3.9(\mathrm{~s}, 6 \mathrm{H}$, $\left.\mathrm{OCH}_{3}\right), 1.7\left(\mathrm{sx}, 2 \mathrm{H}, \mathrm{CH}_{2}, \mathrm{~J}=7.3 \mathrm{~Hz}\right), 1.0\left(\mathrm{t}, 3 \mathrm{H}, \mathrm{CH}_{3}, \mathrm{~J}=7.3 \mathrm{~Hz}\right) ;{ }^{13} \mathrm{C}-\mathrm{NMR} \delta 163(\mathrm{C}=\mathrm{O}), 152(\mathrm{HC}=), 158,140,129,127$, $114(\mathrm{Ph}), 116(\mathrm{CN}), 97(\mathrm{C}=), 67\left(\mathrm{OCH}_{2}\right), 56\left(\mathrm{OCH}_{3}\right), 22\left(\mathrm{OCH}_{2} \mathrm{CH}_{2}\right), 10\left(\mathrm{OCH}_{2} \mathrm{CH}_{2} \mathrm{CH}_{3}\right) ; \mathrm{IR}\left(\mathrm{cm}^{-1}\right): 3050-2820(\mathrm{~m}$, C-H), 2220, (m, CN), 1735 (s, C=O), 1539 (s, C=C), 1278 (s, C-O-C), 820, 726 (s, C-H out of plane). Anal. Calcd. for $\mathrm{C}_{15} \mathrm{H}_{16} \mathrm{ClNO}_{4}$ : C, 58.16; H, 5.21; N, 4.52; Found: C, 57.44; H, 5.00; N, 4.41.

Propyl 2-cyano-3-(5-chloro-2,3-dimetoxyphenyl)-2-propenoate

Yield $82 \%$; mp $92^{\circ} \mathrm{C},{ }^{1} \mathrm{H}-\mathrm{NMR} \delta 8.6(\mathrm{~s}, 1 \mathrm{H}, \mathrm{CH}=), 7.9-7.1(\mathrm{~m}, 2 \mathrm{H}, \mathrm{Ph}), 4.3\left(\mathrm{t}, 2 \mathrm{H}, \mathrm{OCH}_{2}, \mathrm{~J}=7.3 \mathrm{~Hz}\right), 3.9\left(\mathrm{~s}, 6 \mathrm{H}, \mathrm{OCH}_{3}\right)$, $1.8\left(\mathrm{sx}, 2 \mathrm{H}, \mathrm{CH}_{2}, \mathrm{~J}=7.3 \mathrm{~Hz}\right), 1.0\left(\mathrm{t}, 3 \mathrm{H}, \mathrm{CH}_{3}\right) ;{ }^{13} \mathrm{C}-\mathrm{NMR} \delta 163(\mathrm{C}=\mathrm{O}), 152(\mathrm{HC}=), 153,129,121(\mathrm{Ph}), 116(\mathrm{CN}), 111$ $(\mathrm{C}=), 67\left(\mathrm{OCH}_{2}\right), 55\left(\mathrm{OCH}_{3}\right), 22\left(\mathrm{OCH}_{2} \underline{C H}_{2}\right), 10\left(\mathrm{OCH}_{2} \mathrm{CH}_{2} \underline{C H}_{3}\right) ; \mathrm{IR}\left(\mathrm{cm}^{-1}\right): 2913-2836(\mathrm{~m}, \mathrm{C}-\mathrm{H}), 2226(\mathrm{~m}, \mathrm{CN}), 1715$ (s, C=O), 1542 (s, C=C), 1287 (s, C-O-C), 812, 759 (s, C-H out of plane). Anal. Calcd. for $\mathrm{C}_{15} \mathrm{H}_{16} \mathrm{ClNO}_{4}: \mathrm{C}, 58.16 ; \mathrm{H}_{\text {, }}$ 5.21 ; N, 4.52; Found: C, 57.60; H, 5.12; N, 4.46 .

Propyl 2-cyano-3-(4-bromo-2,6-difluorophenyl)-2-propenoate

Yield $84 \%$; mp $76^{\circ} \mathrm{C},{ }^{1} \mathrm{H}-\mathrm{NMR} \delta 8.3(\mathrm{~s}, 1 \mathrm{H}, \mathrm{CH}=), 7.8-7.1(\mathrm{~m}, 2 \mathrm{H}, \mathrm{Ph}), 4.3\left(\mathrm{t}, 2 \mathrm{H}, \mathrm{OCH}_{2}, \mathrm{~J}=7.3 \mathrm{~Hz}\right), 1.7\left(\mathrm{sx}, 2 \mathrm{H}, \mathrm{CH}_{2}\right.$, $\mathrm{J}=7.3 \mathrm{~Hz}), 1.0\left(\mathrm{t}, 3 \mathrm{H}, \mathrm{CH}_{3}, \mathrm{~J}=7.3 \mathrm{~Hz}\right) ;{ }^{13} \mathrm{C}-\mathrm{NMR} \delta 163(\mathrm{C}=\mathrm{O}), 152(\mathrm{HC}=), 153,148,115(\mathrm{Ph}), 116(\mathrm{CN}), 98(\mathrm{C}=), 67$ $\left(\mathrm{OCH}_{2}\right), 22\left(\mathrm{OCH}_{2} \underline{C H}_{2}\right), 10\left(\mathrm{OCH}_{2} \mathrm{CH}_{2} \underline{C H}_{3}\right) ; \mathrm{IR}\left(\mathrm{cm}^{-1}\right): 3150-2810(\mathrm{~m}, \mathrm{C}-\mathrm{H}), 2223(\mathrm{~m}, \mathrm{CN}), 1727(\mathrm{~s}, \mathrm{C}=\mathrm{O}), 1626(\mathrm{~s}$, $\mathrm{C}=\mathrm{C}$ ), 1248 (s, C-O-C), 787 (s, C-H out of plane). Anal. Calcd. for $\mathrm{C}_{13} \mathrm{H}_{10} \mathrm{BrF}_{2} \mathrm{NO}_{2}$ : C, 47.30; H, 3.05; N, 4.24; Found: C, 47.22; H, 2.97; N, 4.21.

Propyl 2-cyano-3-(3-chloro-2,6-difluorophenyl)-2-propenoate

Yield 77\%; mp 50 ${ }^{\circ} \mathrm{C},{ }^{1} \mathrm{H}-\mathrm{NMR} \delta 8.4(\mathrm{~s}, 1 \mathrm{H}, \mathrm{CH}=), 8.0-7.3(\mathrm{~m}, 2 \mathrm{H}, \mathrm{Ph}), 4.2\left(\mathrm{t}, 2 \mathrm{H}, \mathrm{OCH}_{2}, \mathrm{~J}=7.3 \mathrm{~Hz}\right), 1.7\left(\mathrm{sx}, 2 \mathrm{H}, \mathrm{CH}_{2}\right)$, $1.0\left(\mathrm{t}, 3 \mathrm{H}, \mathrm{CH}_{3}, \mathrm{~J}=7.3 \mathrm{~Hz}\right) ;{ }^{13} \mathrm{C}-\mathrm{NMR} \delta 163(\mathrm{C}=\mathrm{O}), 152(\mathrm{HC}=), 151,133,113,111(\mathrm{Ph}), 116(\mathrm{CN}), 98(\mathrm{C}=), 67\left(\mathrm{OC} \mathrm{H}_{2}\right)$, $22\left(\mathrm{OCH}_{2} \underline{\mathrm{CH}}_{2}\right), 10\left(\mathrm{OCH}_{2} \mathrm{CH}_{2} \underline{\mathrm{CH}}_{3}\right)$; IR $\left(\mathrm{cm}^{-1}\right): 3100-2815(\mathrm{~m}, \mathrm{C}-\mathrm{H}), 2223(\mathrm{~m}, \mathrm{CN}), 1728(\mathrm{~s}, \mathrm{C}=\mathrm{O}), 1597(\mathrm{~s}, \mathrm{C}=\mathrm{C})$, 1258 (s, C-O-C), 769 (s, C-H out of plane). Anal. Calcd. for $\mathrm{C}_{13} \mathrm{H}_{10} \mathrm{ClF}_{2} \mathrm{NO}_{2}$ : C, 54.66; H, 3.53; N, 4.90; Found: C, $54.49 ; \mathrm{H}, 3.52 ; \mathrm{N}, 4.83$.

Propyl 2-cyano-3-(4-chloro-2,6-difluorophenyl)-2-propenoate

Yield 52\%; mp $72{ }^{\circ} \mathrm{C},{ }^{1} \mathrm{H}-\mathrm{NMR} \delta 8.2(\mathrm{~s}, 1 \mathrm{H}, \mathrm{CH}=), 8.1-7.5(\mathrm{~m}, 2 \mathrm{H}, \mathrm{Ph}), 4.1\left(\mathrm{t}, 2 \mathrm{H}, \mathrm{OCH}_{2}, \mathrm{~J}=7.3 \mathrm{~Hz}\right), 1.7\left(\mathrm{sx}, 2 \mathrm{H}, \mathrm{CH}_{2}\right)$, $1.0\left(\mathrm{t}, 3 \mathrm{H}, \mathrm{CH}_{3}, \mathrm{~J}=7.3 \mathrm{~Hz}\right) ;{ }^{13} \mathrm{C}-\mathrm{NMR} \delta 162(\mathrm{C}=\mathrm{O}), 150(\mathrm{HC}=), 153,142,133,111(\mathrm{Ph}), 116(\mathrm{CN}), 92(\mathrm{C}=), 67(\mathrm{OCH} 2)$, $22\left(\mathrm{OCH}_{2} \mathrm{CH}_{2}\right), 10\left(\mathrm{OCH}_{2} \mathrm{CH}_{2} \mathrm{CH}_{3}\right)$; IR $\left(\mathrm{cm}^{-1}\right): 3150-2825(\mathrm{~m}, \mathrm{C}-\mathrm{H}), 2223(\mathrm{~m}, \mathrm{CN}), 1726(\mathrm{~s}, \mathrm{C}=\mathrm{O}), 1582(\mathrm{~s}, \mathrm{C}=\mathrm{C})$, 1287 (s, C-O-C), 821, 762 (s, C-H out of plane). Anal. Calcd. for $\mathrm{C}_{13} \mathrm{H}_{10} \mathrm{ClF}_{2} \mathrm{NO}_{2}$ : C, 54.66; H, 3.53; N, 4.90; Found: C, $55.31 ; \mathrm{H}, 3.59 ; \mathrm{N}, 4.96$.

\subsection{Synthesis of Styrene-PCPP Copolymers}

ST and the PCPP monomers were mixed in 25-mL glass screw cap vials at ST/PCPP $=3$ (mol) the monomer feed using 0.12 $\mathrm{mol} / \mathrm{L}$ of $\mathrm{ABCN}$ at an overall monomer concentration $2.44 \mathrm{~mol} / \mathrm{L}$ in $10 \mathrm{~mL}$ of toluene. The mixture was heated at $70^{\circ} \mathrm{C}$ for 5 hours followed by precipitated in methanol forming white flaky precipitates. The new synthesized PCPP compounds copolymerized readily with ST under free-radical conditions (Scheme 2). The conversion of the copolymers was kept between 10 and $20 \%$ to minimize compositional drift (Table 1). Nitrogen elemental analysis showed that between 18.4 and $32.2 \mathrm{~mol} \%$ of PCPP is present in the copolymers, which is indicative of relatively high reactivity of the PCPP monomers towards ST radical. We showed that the PCPP monomers do not homopolymerize under these conditions, therefore the most likely the copolymers' structure would be PCPP centered triads, ST-PCPP-ST separated by short ST sequences (Scheme 2). 


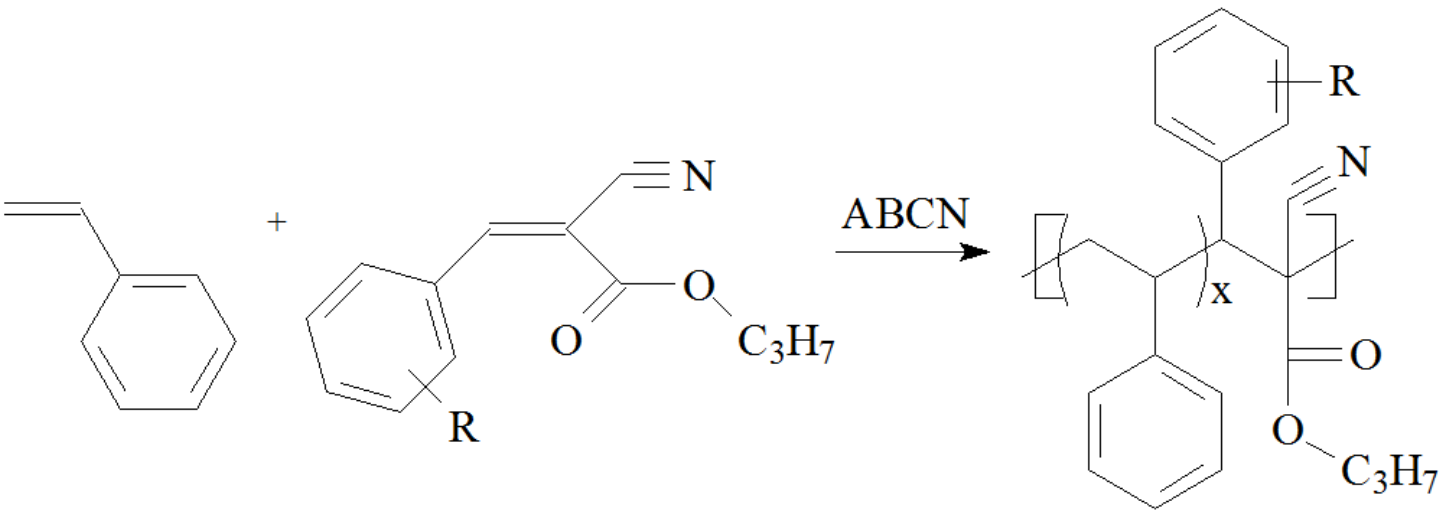

Scheme 2. ST-PCPP copolymer synthesis, $\mathrm{R}=$ 2-bromo-3-hydroxy-4-methoxy, 5-bromo-2,3-dimethoxy, 5-bromo-2,4-dimethoxy, 6-bromo-3,4-dimethoxy, 2-chloro-3,4-dimetoxy, 5-chloro-2,3-dimetoxy, 4-bromo-2,6-difluoro, 3-chloro-2,6-difluoro, 4-chloro-2,6-difluoro

The copolymers prepared in the present work are all soluble in ethyl acetate, THF, DMF and $\mathrm{CHCl}_{3}$ and insoluble in methanol, ethyl ether, and petroleum ether. The molecular weights were measured by GPC in THF. According to GPC analysis the copolymers had weight-average molecular masses 20.8 to $41.4 \mathrm{kD}$ (Table 1).

Table 1. Molecular characteristics of P(ST-co-PCPP) copolymers ${ }^{\mathrm{a}}$

\begin{tabular}{|c|c|c|c|c|c|}
\hline $\mathrm{R}$ & $\begin{array}{c}\text { Nitrogen } \\
\text { wt } \%\end{array}$ & $\begin{array}{c}\% \text { mole } \\
\text { ST }\end{array}$ & $\begin{array}{l}\% \text { mole } \\
\text { PCPP }\end{array}$ & $1 / r_{1}$ & $\begin{array}{l}\mathrm{M}_{\mathrm{W}}^{\mathrm{b}} \\
\mathrm{kD}\end{array}$ \\
\hline 2-Br-3-OH-4-OCH & 2.07 & 76.4 & 23.6 & 1.34 & 36.4 \\
\hline $5-\mathrm{Br}-2,3-\left(\mathrm{OCH}_{3}\right)_{2}$ & 2.37 & 69.5 & 30.5 & 2.35 & 25.3 \\
\hline $5-\mathrm{Br}-2,4-\left(\mathrm{OCH}_{3}\right)_{2}$ & 2.14 & 74.3 & 25.7 & 1.59 & 23.3 \\
\hline $6-\mathrm{Br}-3,4-\left(\mathrm{OCH}_{3}\right)_{2}$ & 2.03 & 76.3 & 23.7 & 1.35 & 20.8 \\
\hline $2-\mathrm{Cl}-3,4-\left(\mathrm{OCH}_{3}\right)_{2}$ & 2.38 & 78.5 & 21.5 & 1.13 & 31.7 \\
\hline $5-\mathrm{Cl}-2,3-\left(\mathrm{OCH}_{3}\right)_{2}$ & 2.55 & 72.9 & 27.2 & 1.79 & 41.4 \\
\hline $4-\mathrm{Br}-2,6-\mathrm{F}_{2}$ & 2.55 & 67.8 & 32.2 & 2.71 & 26.4 \\
\hline $3-\mathrm{Cl}-2,6-\mathrm{F}_{2}$ & 2.54 & 71.7 & 28.3 & 1.96 & 23.6 \\
\hline $4-\mathrm{Cl}-2,6-\mathrm{F}_{2}$ & 2.52 & 71.8 & 28.2 & 1.94 & 25.1 \\
\hline
\end{tabular}

${ }^{a}$ Conditions: ST/PCPP: 3 (mol) / Toluene $/ 70^{\circ} \mathrm{C} / 5$ hrs. ${ }^{b}$ by GPC in THF

Relative reactivities of ST and the PCPP monomers in the copolymerization can be estimated by application of the copolymerization equation for the terminal copolymerization model (Odian 2004)

$$
m_{1} / m_{2}=\left[\mathrm{M}_{1}\right]\left(r_{1}\left[\mathrm{M}_{1}\right]+\left[\mathrm{M}_{2}\right]\right) /\left[\mathrm{M}_{2}\right]\left(\left[\mathrm{M}_{1}\right]+r_{2}\left[\mathrm{M}_{2}\right]\right)
$$

where $m_{1}$ and $m_{2}$ are the mole fractions of ST and PCPP monomer units in the copolymer, $\left[\mathrm{M}_{1}\right]$ and $\left[\mathrm{M}_{2}\right]$ are concentrations of ST and a PCPP in the monomer feed, and $r_{1}$ and $r_{2}$ are monomer reactivity ratios, $r_{1}=k_{\mathrm{ST}-\mathrm{ST}} / k_{\mathrm{ST}-\mathrm{PCPP}}$ and $r_{2}=k_{\text {PCPP-PCPP }} / \mathrm{k}_{\text {PCPP-ST }}$. In the absence of the self-propagation of PCPP monomers $\left(k_{\mathrm{PCPP}-\mathrm{PCPP}}=0, r_{2}=0\right)$, the Eq. 1 yields:

$$
m_{1} / m_{2}=r_{1}\left(\left[\mathrm{M}_{1}\right] /\left[\mathrm{M}_{2}\right]\right)+1
$$

Equation 2 assumes a minimal copolymer compositional drift during a copolymerization reaction, i.e. a low conversion. The fact that PCPP monomers do not self-propagate allows the use of Eq. 2 for a single-point estimation of the relative reactivity of PCPP monomers with respect to ST; it is represented by the $1 / r_{1}=k_{\mathrm{ST} \text {-PCPP}} / k_{\mathrm{ST}-\mathrm{ST}}$ ratio (the rate constant ratio of attaching a PCPP molecule vs. a ST molecule to ST-ending growing polymer chain). Taking into account that the $\left[\mathrm{M}_{1}\right] /\left[\mathrm{M}_{2}\right]$ ratio in all the experiments was equal to 3.0 , relative reactivities $1 / r_{1}$ for PCPP monomers decrease in the following row $\mathrm{R}=4-\mathrm{Br}-2,6-\mathrm{F}_{2}(2.71)>5-\mathrm{Br}-2,3-\left(\mathrm{OCH}_{3}\right)_{2}(2.35)>3-\mathrm{Cl}-2,6-\mathrm{F}_{2}(1.96)>4-\mathrm{Cl}-2,6-\mathrm{F}_{2}$ (1.94) > 
$5-\mathrm{Cl}-2,3-\left(\mathrm{OCH}_{3}\right)_{2} \quad(1.79)>5-\mathrm{Br}-2,4-\left(\mathrm{OCH}_{3}\right)_{2}(1.59)>6-\mathrm{Br}-3,4-\left(\mathrm{OCH}_{3}\right)_{2} \quad(1.35)>2-\mathrm{Br}-3-\mathrm{OH}-4-\mathrm{OCH}_{3} \quad(1.34)>$ 2-Cl-3,4-( $\left(\mathrm{OCH}_{3}\right)_{2}(1.13)$. These ratios signify that all ring-trisubstituted PCPP monomers are more reactive than styrene in the addition to a ST-ended polymer radical $\left(1 / \mathrm{r}_{1}>1\right)$.

\subsection{Structure and Thermal Properties}

The ST-PCPP copolymers were characterized by IR and NMR spectroscopy. The spectra of the monomers were compared with those of copolymers and polystyrene thus providing evidence that the reaction between the PCPP monomers and ST is a copolymerization. The C-H stretch vibrations are observed in $3200-2800 \mathrm{~cm}^{-1}$ region. PCPP showed absorptions at 2244-2233 (w, CN), 1748-1725 (s, C=O), and 1256-1212 $\mathrm{cm}^{-1}$ (s, C-O). Vibrations at $1500-1400 \mathrm{~cm}^{-1}$ as well as a doublet 800-700 $\mathrm{cm}^{-1}$ are associated with ST and PCPP rings stretching bands, as well as with C-H out-of-plane deformations.

ST-PCPP copolymers microstructure analysis is based on ${ }^{1} \mathrm{H}$ - and ${ }^{13} \mathrm{C}-\mathrm{NMR}$ spectroscopy (DEPT, HETCOR, NOESY and JMODXH) of ST copolymers with 2-phenyl-1,1-dicyanoethene (Kharas, Murau, Watson, \& Harwood, 1992) which showed the formation of both head-to-tail and head-to-head alternating monomer structures, as well as short ST sequences. A broad double peak in a 5.0-7.5 ppm region in the ${ }^{1} \mathrm{H}-\mathrm{NMR}$ spectra of the ST-PCPP copolymers corresponds to phenyl protons. The methyleneoxy protons of propyl ester in both head-to-tail $(\mathrm{H}-\mathrm{T})$ structure and head-to-head $(\mathrm{H}-\mathrm{H})$ structure are observed in 4.4-4.0 ppm region. The methylene protons of H-T structures and methine protons of ST in $\mathrm{H}-\mathrm{H}$ structures as well as methine protons of PCPP in both structures are represented by broad overlapping resonances at 4.0-2.7 ppm. Methoxy protons of PCPP absorb in 4.0-3.5 ppm. The methine and methylene protons of ST monomer sequences as well as to PCPP ester methylene protons are attributed to a broad resonance peak in 2.0-0.8 ppm range, whereas methyl groups of PCPP propyl ester are represented by the absorption in 1.0-0.4 ppm.

In ${ }^{13} \mathrm{C}$-NMR spectra of the copolymers, the carbonyl of the PCPP propyl ester group is associated with the peak in 162-157 ppm range. Absorptions in 120-115 ppm range are assigned to nitrile carbon, whereas phenyl carbon resonances of ST and PCPP are observed in 147-120 ppm range. Absorption of methyleneoxy carbon of propyl ester in both H-T and H-H alternating ST-PCPP structures is observed at $68-63 \mathrm{ppm}$. Methoxy carbons of PCPP monomer unit are assigned to resonance in 57-52 ppm range. Signals for PCPP quaternary and methine carbons in H-H structure B are assigned to overlapping absorptions at 55-52 ppm. ST methylene and methine carbons are observed at 48-33 ppm. Methylene carbons of propyl group and methyl carbon result in signals at 23-19 ppm and at $10 \mathrm{ppm}$, respectively. Head-to-tail and head-to-head structures, which might form via the attack of ST-ended radical on both sides of PCPP monomer or/and participation of both free monomers and monomer donor-acceptor complexes (Odian 2004) might be associated with broadening of the NMR signals. The IR and NMR data showed that these are true copolymers, composed of both TSE and ST monomer units.

DSC analysis confirmed amorphous morphology of the ST-PPCA copolymers showing glass transition temperatures $T_{\mathrm{g}}$ and absence of crystalline endotherm on repeated heating and cooling cycles (Table 2).

Thermogravimetric analysis provided information on thermal stability of the copolymers (Table 2).

Table 2. Thermal Analysis of P(ST-co-PCPP) copolymers

TGA

\begin{tabular}{|c|c|c|c|c|c|}
\hline $\mathrm{R}$ & $\begin{array}{l}\mathrm{T}_{\mathrm{g}} \\
{ }^{\circ} \mathrm{C}\end{array}$ & Onset of decomp., ${ }^{\circ} \mathrm{C}$ & $10 \%$ wt loss, ${ }^{\circ} \mathrm{C}$ & $50 \%$ wt loss, ${ }^{\circ} \mathrm{C}$ & Residue at $500{ }^{\circ} \mathrm{C}, \mathrm{wt} \%$ \\
\hline 2-Br-3-OH-4-OCH & 112 & 202 & 297 & 337 & 5.3 \\
\hline 5-Br-2,3-( $\left(\mathrm{OCH}_{3}\right)_{2}$ & 111 & 211 & 292 & 340 & 4.2 \\
\hline $5-\mathrm{Br}-2,4-\left(\mathrm{OCH}_{3}\right)_{2}$ & 127 & 213 & 276 & 344 & 5.6 \\
\hline 6-Br-3,4-( $\left(\mathrm{OCH}_{3}\right)_{2}$ & 126 & 224 & 277 & 338 & 4.2 \\
\hline $2-\mathrm{Cl}-3,4-\left(\mathrm{OCH}_{3}\right)_{2}$ & 119 & 231 & 286 & 353 & 4.5 \\
\hline 5-Cl-2,3-( $\left(\mathrm{OCH}_{3}\right)_{2}$ & 121 & 206 & 289 & 359 & 4.2 \\
\hline $4-\mathrm{Br}-2,6-\mathrm{F}_{2}$ & 118 & 272 & 275 & 361 & 7.1 \\
\hline $3-\mathrm{Cl}-2,6-\mathrm{F}_{2}$ & 128 & 291 & 284 & 364 & 8.1 \\
\hline $4-\mathrm{Cl}-2,6-\mathrm{F}_{2}$ & 125 & 282 & 288 & 380 & 6.9 \\
\hline
\end{tabular}

Thermal stability of the P(ST-co-PCPP) copolymers is lower than that of polystyrene, PS (Ellison et al., 2005, Petrson et al., 2001), the onset of decomposition at $202-291^{\circ} \mathrm{C}$ (PS $350^{\circ} \mathrm{C}$ ), $10 \%$ weight loss at $275-297^{\circ} \mathrm{C}$ (PS $425^{\circ} \mathrm{C}$ ), $50 \%$ weight loss at $337-380^{\circ} \mathrm{C}\left(\mathrm{PS} 428^{\circ} \mathrm{C}\right.$ ). Lower thermal stability of the copolymers apparently associated with presence of PCPP quaternary carbon in the chain similarly to poly-alpha-methylstyrene (Lina et al., 2012). Information on the degradation of 
the copolymers was obtained from thermogravimetric analysis. Decomposition of the copolymers in nitrogen occurred in two steps, first in the $200-500^{\circ} \mathrm{C}$ range with residue (4.2 $-8.1 \%$ wt.), which then decomposed in the $500-800^{\circ} \mathrm{C}$ range. The decomposition products were not analyzed in this study, and the mechanism has yet to be investigated.

\section{Conclusions}

New phenyl-trisubstituted propyl 2-cyano-3-(R-phenyl)-2-propenoates (where $\mathrm{R}$ is 2,4,5-trimethyl, 2,4,6-trimethyl, 2,3-dimethyl-4-methoxy, 2,5-dimethyl-4-methoxy, 2,4-dimethoxy-3-methyl, 2,4-dimethoxy-6-methyl, 4-hydoxy-3,5-dimethyl, 2,3,4-trimethoxy, 2,4,5-trimethoxy, 2,4,6-trimethoxy, 3,4,5-trimethoxy) were prepared using piperidine catalyzed condensation of substituted benzoic aldehydes and propyl ester of cyanoacetic acid. The styrene copolymerization of propenoates in solution with radical initiation resulted in formation of copolymers with $M_{\mathrm{W}} 20.8$ to $41.4 \mathrm{kD}$ and $21.5-32.2 \mathrm{~mol} \%$ of propenoate. Thermal behavior of the copolymers was studied by DSC, $T_{\mathrm{g}}\left(111-128^{\circ} \mathrm{C}\right)$ and TGA. Decomposition of the copolymers in nitrogen occurred in two steps, first in the $200-500^{\circ} \mathrm{C}$ range with residue $(4.2$ $-8.1 \%$ wt.), which then decomposed in the $500-800^{\circ} \mathrm{C}$ range.

\section{References}

Angelovici, M. M., \& Kohn, D. H. (1990). Copolymerization of acrylic esters with ethyl $\alpha$-cyanocinnamate. J. Appl. Polym. Sci. 40, 485-494. https://doi.org/10.1002/app.1990.070400315

Bates, J., Krider, A. L., Malik, S. A., May, D. P., Stryelkina, M., Williams, C. G., ...Kharas, G. B. (2019). Synthesis and styrene copolymerization of novel chloro and fluoro ring-trisubstituted propyl cyanophenylpropenoates. International Journal of Chemistry, 11, 79-83. https://doi.org/10.5539/ijc.v11n1p79

Cativiela, C., Diaz-de-Villegas, M. D., \& Galvez, J. A. (1992). Chiral 2-cyanocinnamates in conjugate addition asymmetric enolate trapping reactions. Bull. Chem. Soc. of Japan, 65, 1657-1661. https://doi.org/10.1246/bcsj.65.1657

Ellison, C. J., Mundra, M. K., \& Torkelson, J. M. (2005). Impacts of Polystyrene Molecular Weight and Modification to the Repeat Unit Structure on the Glass Transition -Nanoconfinement Effect and the Cooperativity Length Scale. Macromolecules, 38, 1767-1778. https://doi.org/10.1021/ma047846y

Hall, H. K., Jr., \& Daly, R. C. (1975). Electron-Deficient Trisubstituted Olefins. A New Class of Reactive Comonomers. Macromolecules, 8, 22-29. https://doi/org/10.1021/ma60043a006

Hall, H. K., Jr., \& Ykman, P. (1977). Trisubstituted ethylenes containing halo, cyano, and carbomethoxy substituents. New reactive comonomers. Macromolecules, 10, 464-469. https://doi.org/10.1021/ma60056a044

Humanski, K. E., Patterson, S. D., Pecorin, P. J., Perfitt, M. M., Romero, J., Sassack, W. R., ... Kharas, G. B. (2018). Synthesis and styrene copolymerization of novel trisubstituted ethylenes: 11. Halogen ring-substituted propyl 2-cyano-3-phenyl-2-propenoates. J. Macromol. Sci., A55, 709-717. https://doi.org/10.1080/10601325.2018.1526639.

Kharas, G. B. (1996). Trisubstituted Ethylene Copolymers. In J. C. Salamone, J. C., (Ed.), Polymeric Materials Encyclopedia (Vol. 11, 8405-8409). Boca Raton, FL. USA: CRC Press.

Kharas, G. B., Bates, J., Boyd, A. T., Burke, J. N., Crosby, J. L., Sundquist, S. B., ... Bromby II, P. L. (2017). Novel copolymers of styrene. 10. Bromo and chloro ring-disubstituted propyl 2-cyano-3-phenyl-2-propenoates. $J$. Macromol. Sci., A54, 372-375. https://doi.org/10.1080/10601325.2017.1312679

Kharas, G. B., Murau, P. A., Watson, K., \& Harwood, H J. (1992). Microstructure of styrene copolymers with 2-phenyl-1,1-dicyanoethene. Polymer International, 28, 67-74. https://doi.org/10.1002/pi.4990280112

Kharas, G. B., Rocus, S. M., Locke, M. C., Macke, W. J., Oh, S. S., Pagan, N. A., ... Weingart, J. (2016). Novel copolymers of styrene. 14. Halogen Ring-trisubstituted butyl 2-cyano-3-phenyl-2-propenoates. J. Macromol. Sci., A53, 465-469. https://doi.org/10.1080/10601325.2016.1189278

Kharas, G. B., Shahbein, A., Asciutto, M. J., Blanc, L. E., Bostrom, S. M., Cherala, S. S., ... Wolfe, C. (2014). Novel copolymers of styrene. 17. Ring-trisubstituted methyl 2-cyano-3-phenyl-2-propenoates. J. Macromol. Sci., A51, 849-853. https://doi.org/10.1080/10601325.2014.953363

Kumar, K. A., Rai, K. M. L., \& Umesha, K. B. (2001). Synthesis and evaluation of antifungal and antibacterial activity of ethyl 3,5-diarylisoxazole-4-carboxylates. J. Chem. Res., Synopses, 10, 436-438. https://doi.org/10.3184/030823401103168389

Lina, Y., Sufen, C., Yong, H., Bo, L., Zhanwen, Z., \& Junxiao, Y. (2012). Thermal degradation kinetics of poly-alpha-methylstyrene. High Power Laser and Particle Beams, 24, 2400-2404.

https://doi.org/10.3788/hplpb20122410.2400 
Nishikubo, T., Kameyama, A., Hayashi, N., \& Nakagome, R. (1995). Synthesis of a new photoreactive polyester by addition reaction of bisepoxide with $\beta$-truxinoyl chloride and chemical modification of this polymer. High Performance Polymers, 7, 245-254. https://doi.org/10.1088/0954-0083/7/3/001

Odian, G. (2004). Principles of Polymerization (4th ed.), New York, NY: Wiley-Interscience. https://doi.org./10.1002/047147875X

Petrson, J. D., Vyazovkin, S., \& Wight, C. A. (2001). Kinetics of the Thermal and Thermo-Oxidative Degradation of Polystyrene, Polyethylene and Poly(Propylene). Macromol. Chem. Phys., 202, 775-784. https://doi.org/10.1002/1521-3935(20010301)202:6<775::aid-macp775>3.0.co;2-g

Rodrigues, N., Bennis, K., Vivier, D., Pereira, V., Chatelain, F. C., Chapuy, E., ... Eschalier, A. (2014). Synthesis and structure-activity relationship study of substituted caffeate esters as antinociceptive agents modulating the TREK-1 channel. European Journal of Medicinal Chemistry, 75, 391-402. https://doi.org/10.1016/j.ejmech.2014.01.049

Ronel, S. H., \& Kohn, D. H., (1975). Terpolymerization studies. I. Terpolymerization of acrylonitrile, styrene, and esters of a-cyanocinnamic acid. J. Appl. Polym. Sci. 19, 2359-2377. https://doi.org/10.1002/app.1975.070190902

Sayed, A. Z., Aboul-Fetouh, M. S., \& Nassar, H. S. (2012). Synthesis, biological activity and dyeing performance of some novel azo disperse dyes incorporating pyrazolo[1,5-a]pyrimidines for dyeing of polyester fabrics. Journal of Molecular Structure, 10, 146-151. https://doi.org/10.1016/j.molstruc.2011.11.046

Smith, M. B., \& March, J. (2001). Addition to Carbon-Hetero Multiple Bonds, In March's Advanced Organic Chemistry. Ch.16, 1225. New York, NY: Wiley \& Sons. https://doi.org/10.1002/9780470084960.ch15

Watanabe, S., \& Ichimura, K. (1982). The selective intermacromolecular photocrosslinking of poly(vinyl cinnamate) derivatives. A new method for improvement of photosensitivity. J. Polym. Sci. Polym. Chem. Ed., 20, 3261-3263. https://doi.org/10.1002/pol.1982.170201122

\section{Copyrights}

Copyright for this article is retained by the author(s), with first publication rights granted to the journal.

This is an open-access article distributed under the terms and conditions of the Creative Commons Attribution license (http://creativecommons.org/licenses/by/4.0/). 